\title{
The Effect of Service Quality on Customer Satisfaction at Koperasi Karyawan PT. Lotus Indah Textile Industry
}

\author{
Damarsari Ratnasahara Elisabeth ${ }^{1,}$ Akhmad Nasir ${ }^{2,}$ Joko Suyono $^{3}$ \\ ${ }^{1}$ Sekolah Tinggi Ilmu Ekonomi Mahardhika, Management Department, Surabaya, \\ Indonesia. \\ ${ }^{2}$ Sekolah Tinggi Ilmu Ekonomi Gempol, Management Department, Gempol Pasuruan, \\ Indonesia. \\ ${ }^{3}$ Universitas Narotama, Department of Management and Business, Surabaya, Indonesia. \\ damarsariarizona@gmail.com
}

\begin{abstract}
This type of research uses a correlation coefficient, the sample used in this study is members who are also customers of Koperasi Karyawan PT. Lotus Indah Textile Industry in Surabaya as many as 50 customers who actively transact as many as 5 to 6 times each month. Processing data using validity test, reliability test and hypothesis test using t-test. The results of the correlation coefficient analysis using the SPSS 22.0 program amounted to 0.544 which means that there is an influence between employee service quality (x) on customer satisfaction (y). The results of the discussion and the results of testing the independent variable (x) service quality with dependent variables (y) customer satisfaction that $\mathrm{H} 0$ is rejected and $\mathrm{H} 1$ is accepted, because with $\mathrm{t}$-count of $4.4917>t$ table of 1.6672. This means that there is an influence of variable $(\mathrm{x})$ on variable $(\mathrm{y})$.
\end{abstract}

Keywords: service quality, customer satisfaction

\section{INTRODUCTION}

The Indonesian government continues to spur an increase investment in the textile and textile products (TPT) industry because it contributes greatly to national economic growth. The textile industry is an important sector in the Indonesian economy, given its significant contribution to GDP. Until the third quarter of 2015, this sector was able to contribute 1.17 percent of GDP. (http://poskotanews.com/ 2016/01/23/). Koperasi Karyawan PT. Lotus Indah Textile Industry in Surabaya is a cooperative engaged in savings and loans and retail products for daily needs. In the face of intense competition, Koperasi Karyawan PT. Lotus Indah Textile Industry in Surabaya needs to increase new products and quantity of goods, the quality of services provided to customers, because customers begin to demand fulfillment of their psycho-social needs, namely higher value and more specific services and relatively more price levels cheap compared to other shops.

To reach the situation as described above, understanding consumer behavior is very important, because the understanding of consumer behavior in choosing goods or services producers can know exactly what the customer needs and wants. Similarly, Koperasi Karyawan PT. Lotus Indah Textile Industry in Surabaya which is engaged in retail and savings and loans which gets the opportunity to meet basic needs and savings and loans with good service so that customers return to Koperasi Karyawan PT. Lotus Indah Textile Industry in Surabaya.

\section{Formulation of the Problem}

The effect of service quality on customer satisfaction at Koperasi Karyawan PT. Lotus Indah Textile Industry Damarsari Ratnasahara Elisabeth, Akhmad Nasir, Joko Suyono 
In accordance with the background of the problem above, the formulation of the problem can be as follows:

"Does the quality of service affect customer satisfaction?"

\section{LITERATURE REVIEWS AND HYPOTHESES}

\section{Definition of Services}

According to Philip Kotler and Anderson (1995:541) "service is any action that can be offered by a party to another party", which is basically intangible (not tangible physical) and does not produce ownership of something, production services can relate to products physical or not.

While according to Barata (2003: 9) "service is the process of providing certain services from the service provider to the parties served".

Based on the two terms of service, that every action or action that can be offered by the service provider to the parties served.

\section{Quality}

Quality is a dynamic condition that relates to products, services, people, processes, and environments that meet or exceed expectations (Goetsch et. Al., 2002: 4). Deming defines quality is a predictable level of uniformity and dependence on low costs and in accordance with the market. Meanwhile J. M. Juran is quoted in Tjiptono (2001) interpreting it as suitable for use (fitness for use). Quality is one of the things that customers look for in an offer, which service happens to be one (Solomon 2009, p. 413). Quality can also be defined as the totality of features and characteristics of a product or services that bear on its ability to satisfy stated or implied needs (Kotler et al., 2002, p. 831). It is evident that quality is also related to the value of an offer, which could evoke satisfaction or dissatisfaction on the part of the user.

\section{Service Quality}

Before defining service quality, first define quality according to Boone and Kuntz (2005). "the degree of excellence or superiority of an organization of goods and services", meaning quality is an superiority of the goods and services produced by an organization". Service quality, according to Zeithaml and Berry (1985) "Only Customer Judge Quality", besides the quality of business entities is the customer's own perception. A good perception arises when the customer has good experience with the quality of the product produced by the business entity or corporation, if the customer is satisfied with the product provided by the business entity or corporation but because the service provided is not good it will reduce customer satisfaction to the business entity or corporation. Based on the two notions of service quality, that quality is important where every marketer strives to attract customers with the quality of the product produced. Service quality in the management and marketing literature is the extent to which customers' perceptions of service meet and/or exceed their expectations for example as defined by Zeithaml et al. (2006), cited in Bowen \& David, 2005, p. 340). Thus service quality can intend to be the way in which customers are served in an organization which could be good or poor. Parasuraman defines service quality as "the differences between customer expectations and perceptions of service" (Parasuraman, 1988). They argued that measuring service quality as the difference between perceived and expected service was a valid and could make management to identify gaps to what they offer as services. The aim of providing quality services is to satisfy customers. way and could make management to identify gaps to what they offer as services. The aim of providing quality services is to satisfy customers.

Services have a unique characteristic. According to Philip Kotler and Gary Armstrong (2016) these characteristics are as follows:

1. Intangibility, which means that intangible services cannot be seen before a purchase transaction occurs. So that it can only be felt when you have received the service.

2. Insperability, which means that the service cannot be separated from the service provider.

3. Variability which means that the service is volatile depending on the service provider. 
4. Perishability which means that services cannot be stored or are not durable, once received, it is immediately felt at that moment.

Service quality can be assessed based on customer perceptions, it was stated by Zeithaml, A. Parasuraman and Berry (1985) which states that: "service quality is the customer perception of the superioty of the service", service quality is the experience of consumer perception, good perception will arise if the customer has good experience and is satisfied with the quality of service provided by a business entity or corporation, as well as if the customer has a bad experience so that he is not satisfied with the quality of services provided, a bad perception will arise.

\section{Customer Satisfaction}

Customer is the person who does the buying of the products and the consumer is the person who ultimately consumes the product (Solomon, 2009, p. 34.). When a consumer/customer is happy with either the product or services it is termed satisfaction. Satisfaction can also be a person's feelings of pleasure or disappointment that results from comparing a product's perceived performance or outcome with their expectations (Kotler \& Keller, 2009, p. 789).

According to Davis (2010) "customer satisfaction, is the customer's response to the evaluation of the perceived incompatibility between the previous expectations and the actual performance of the product that is felt after its use". Philip Kotler and Gary Armstrong (2016) define "customer satisfaction is the assumption that product performance meets buyer expectations. If product performance is lower than customer expectations, buyer or customers are not satisfied. If product performance matches or exceeds expectations, buyers or customers feel satisfied or very happy." Based on the two meanings above, the dominant factors determine, maintain and grows the company are customer response or experience after using the products.

Today customer satisfaction is one of the strategies to win the competition, this causes more business entities involved in their efforts to place an orientation on customer satisfaction. According to Philip Kotler (1997:40): "customer satisfaction is a person's feelines of pleasure or disappointment resulting from comparing a product perceived performance or outcome in relation to his or her expectations". Customer satisfaction is the level of one's feelings after comparing the benefits or values that he feels compared to his expectations. Customer satisfaction is very important for the success of a business entity, as stated by Dutha (1994:21) "satisfied customers are absolutely vital to bussiness success." Satisfied customers they will buy the product again and recommend the product to their friends.

According to Kotler (2002: 158) in determining the level of customer satisfaction, there are five main factors that must be considered by the company, namely:

1. Product Quality

Consumers will be satisfied if the results of their evaluation show that the products they use are of high quality.

\section{Service Quality}

Especially for the service industry, consumers will feel satisfied if they get good or appropriate service.

3. Emotional

Consumers will feel proud and get confidence that other people will be amazed at him when using products with certain brands that tend to have a higher level of satisfaction.

4. Price

Products that have the same quality but set a relatively cheap price will give a higher value to consumers.

5. Costs

Consumers who do not need to incur additional costs or do not need to waste time getting a product or service tend to be satisfied with the product or service. 


\section{Hypothesis}

As per the formulation of the problem revealed above, the hypothesis proposed is: quality of service influences customer satisfaction at Koperasi Karyawan PT. Lotus Indah Textile Industry in Surabaya. With the research model as follows:

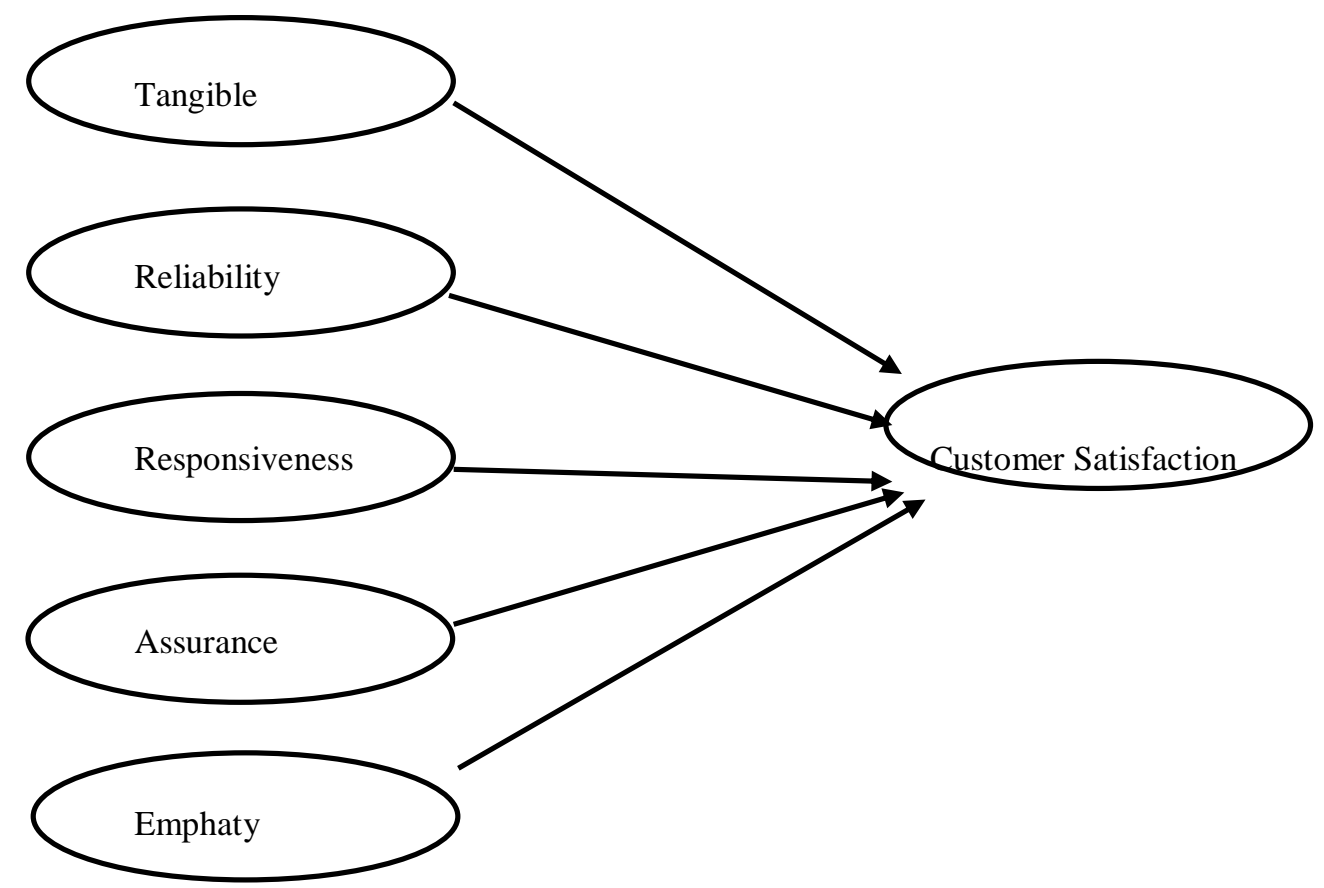

Figure 1 : Research Model

\section{METHODS}

\section{Population and Sample}

Supardi (2012: 101) defines population as an individual or subject unit in the region and time and certain qualities that will be observed or examined. According to Subagyo (2006: 23) the population is used as a determination and limitation of the object of research so that there is no plural interpretation of all existing problems and facilitate researchers in making data retrieval that is relevant to research problems. In this study, the population of this study is the regular customers at Koperasi Karyawan PT. Lotus Indah Textile Industri in Surabaya and the population target in this study is 50 permanent customers who are active transact up to 5 or 6 times each month.

\section{Data Analysis Techniques}

In accordance with the objectives in the research hypothesis proposed, then to examine the relationship between independent variables and dependent variables, the authors use multiple linear regression analysis with the help of SPSS for Windows 22.0. 


\section{RESULT AND DISCUSSION}

To determine the extent of the relationship between the observed variables, the interpretation of the magnitude of the correlation coefficient is used as follows:

Table 1: Correlation Coefficient Value

\begin{tabular}{|c|c|}
\hline Correlation Coefficient Value & Degree of Relationship \\
\hline $0.20-0.40$ & Weak \\
$0.40-0.70$ & Fairly Strong \\
$0.70-1.00$ & Strong \\
\hline
\end{tabular}

Source: Djarwanto PS. And Subagio (2001)

\section{Correlation coefficient}

As mentioned above, the relationship between service quality and customer satisfaction is said to be positive if the value of service quality is high, then the value of customer satisfaction is also high.

Table 2 : Correlations

\begin{tabular}{|c|c|c|c|c|}
\hline & & & $\mathbf{X}$ & $\mathbf{Y}$ \\
\hline Spearman's rho & $\mathrm{X}$ & $\begin{array}{l}\text { Correkation Coefficient } \\
\text { Sig. (2-tailed) } \\
\text { N }\end{array}$ & $\begin{array}{r}1.000 \\
50\end{array}$ & $\begin{array}{r}.544^{88} \\
.000 \\
50\end{array}$ \\
\hline & $\mathrm{Y}$ & $\begin{array}{l}\text { Correkation Coefficient } \\
\text { Sig. (2-tailed) } \\
\text { N }\end{array}$ & $\begin{array}{r}.544 \\
.000 \\
50\end{array}$ & $\begin{array}{r}1.000 \\
50\end{array}$ \\
\hline
\end{tabular}

The calculation results of the correlation coefficient, in the correlation table above the magnitude of the correlation $\mathrm{X}$ and $\mathrm{Y}$ is equal to 0.544 with a significance level of 0,000 , meaning that the variable service quality (x) has a fairly strong with customer satisfaction (y), thus the hypothesis that the authors propose is proven to be true.

Table 3: SPSS Caalculation

\begin{tabular}{|l|c|l|}
\hline Variable & t-count & Sig \\
\hline Service Quality & 4.4917 & 0.000 \\
\hline
\end{tabular}

Signicance of t-test, for service quality $(\mathrm{x})$ significance is $0.000<0.05$. It can be decided that service quality partially has a real effect toward customer satisfaction at Koperasi Karyawan PT. Lotus Indah Textile Industry in Surabaya

\section{CONCLUSION}

The effect of service quality on customer satisfaction at Koperasi Karyawan PT. Lotus Indah Textile Industry Damarsari Ratnasahara Elisabeth, Akhmad Nasir, Joko Suyono 
Based on the results of the analysis and discussion previously stated, conclusions can be taken as follows:

1. In general, the service quality of Koperasi Karyawan PT. Lotus Indah Textile Industry in Surabaya has a high level of expectation on customer satisfaction, this can be seen and illustrated in the results obtained from this study where the level of service quality with customer satisfaction shows a strong and significant influence, where the correlation coefficient is 0.544 which shows that between the two variables, namely the service quality variable (x) and the customer satisfaction variable (y) has a strong relationship.

2. Based on the calculation of t-test, the hypothesis of the relationship between service quality and customer satisfaction is obtained by the significance of service quality $0.000<0.05$, this indicates the level of significance between variables $(\mathrm{x})$ and variables $(\mathrm{y})$. Thus the hypothesis that the authors propose is that there is a positive influence between service quality (x) and customer satisfaction (y) is to be true.

\section{REFERENCES}

Anoraga, Panji and Ninik Widiyanti (2011). Psychology in the Company, Jakarta: Rineka Cipta.

Arikunto, Suharsimi (2006). Prosedur Penelitian Suatu Pendekatan Praktik. Jakarta : Rineka Cipta.

Assauri, Sofyan (2008). Manajemen Produksi dan Operasi, Jakarta: Lembaga Penerbit Fakultas Ekonomi Universitas Indonesia.

Bowen and David E., (2005). Service Quality Blackwell Encyclopaedic Dictionary of Human Resource management, $\mathrm{Pl} 341,340 \mathrm{P}$

Broussard, S. C., \& Garrison, M. E. B. (2004). The relationship between classroom motivation and academic achievement in elementary school-aged children. Family and Consumer Sciences Research Journal, 33(2), 106-120.

Deci, E. L., Koestner, R., \& Ryan, R. M. (1999). A meta-analytic review of experiments examining the effects of extrinsic rewards on intrinsic motivation. Psychological Bulletin, 125(6), 627-668.

Goetsch, David L. And Staanley B. Davis, (2002). Pengantar Manajemen Mutu, Indonesian Version, Jakarta: PT. Prenhalindo.

Guay, F., Chanal, J., Ratelle, C. F., Marsh, H. W., Larose, S., \& Boivin, M. (2010). Intrinsic, identified, and controlled types of motivation for school subjects in young elementary school children. British Journal of Educational Psychology, 80(4), 711-735.

Hasibuan, Malayu SP, (2013). Manajemen Sumber Daya Manusia, Jakarta: Bumi Aksara.

Herdjrachman, Ranupandojo and Saud Husnan, (2000). Manajemen Personalia, Yogyakarta: BPFE UGM. http://poskotanews.com/ 2016/01/23, dowlodad on 23 January 2016 at 20.30

Komarudin, (2011). Manajemen Sumber Daya Manusia, Bandung: Kappa Sigma.

Kotler P., Armstrong G., Saunders J. Wong V., (2002). Principle of Marketing, 3rd edition, Prentice Hall Europe.

Kotler, P. and Keller, K. L., (2009). Marketing management (13th end). New Jersey: Pearson Education Inc, Upper Saddle River,

Martocchio, J.J., (2015). Strategic Compensaton: A Human Resource Management Approach, New Jersey: Pearson

Manullang, M, (2002). Manajemen Personalia, Jakarta: Ghalia Indonesia.

Milkovich, G., Newman, J., and Gerhant, B., (2011).Compensation, New York: McGraw-Hill Irwin

Moekiyat, (1997). Manajemen Kepegawaian, Bandung: CV. Mandar Maju

The effect of service quality on customer satisfaction at Koperasi Karyawan PT. Lotus Indah Textile Industry 
Nitisemito, Alex S, (2014). Manajemen Personalia, Jakarta: Ghalia Indonesia.

Parasuraman, A., Zeithaml, V. A., \& Berry, L. L. (1988). SERVQUAL: A multiple-item scale for measuring consumer perceptions of service quality. Journal of Retailing, 64 (1), 12-40.

Ranupandojo and Husnan, (2000). Organisasi dan Motivasi: Pasar Peningkatan Produktivitas, Jakarta: Bumi Aksara.

Salisono, Slamet, (1993). Civil Service Administration, Jakarta.

Sedarmayanti, (2011). Manajemen Sumber Daya Manusia, Reformasi Birokrasi dan Manajemen Pegawai Negeri Sipil. Bandung : PT Refika Aditama

Solomon, Micheal. R., (2009). Consumer behaviour, Buying, Having and Being, 8th edition, New York: Pearson education, inc.

Susanto R and Indrio Gito Sudarmo, (1996). Manajemen Produksi, Yogyakarta: BPFE UGM.

The Liang Gie, (2002). Administrasi Perkantoran Modern, Yogyakarta: Liberty.

Tjiptono, (2001). Manajemen Pemasaran dan Analisa Perilaku Konsumen, Yogyakarta: BPFE

Turner, J. C. (1995). The influence of classroom contexts on young children's motivation for literacy. Reading Research Quarterly, 30(3), 410-441.

William B. Werther, Jr.Keith Davis, (2000). Human Resources and Personal Management. New York: Mcgraw-Hill, Inc.

Winardi, (1993). Azaz-Azaz Manajemen, Jakarta: Alumni

Zeithaml V. A., Bitner M. J., Gremler D. D., (2006). Services marketing, 4th edition, New York: McGrawHill 